\title{
Miranda
}

Revue pluridisciplinaire du monde anglophone /

Multidisciplinary peer-reviewed journal on the English-

speaking world

$18 \mid 2019$

Guerre en poésie, poésie en guerre

\section{Piecing the Puzzle Together: An Interview with Writer and Artist Mark SaFranko}

Entretien avec l'écrivain américain Mark SaFranko dans le cadre du projet ARIEL (Auteurs en Résidence Internationale En Lorraine), le 20 décembre 2018

\section{Claudine Armand}

\section{OpenEdition}

\section{Journals}

\section{Electronic version}

URL: http://journals.openedition.org/miranda/19606

DOI: 10.4000/miranda.19606

ISSN: 2108-6559

Publisher

Université Toulouse - Jean Jaurès

\section{Electronic reference}

Claudine Armand, "Piecing the Puzzle Together: An Interview with Writer and Artist Mark SaFranko", Miranda [Online], 18 | 2019, Online since 02 May 2019, connection on 16 February 2021. URL: http:// journals.openedition.org/miranda/19606 ; DOI: https://doi.org/10.4000/miranda.19606

This text was automatically generated on 16 February 2021.

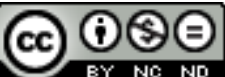

Miranda is licensed under a Creative Commons Attribution-NonCommercial-NoDerivatives 4.0 International License. 
Piecing the Puzzle Together: An Interview with Writer and Artist Mark SaFranko

Entretien avec l'écrivain américain Mark SaFranko dans le cadre du projet ARIEL (Auteurs en Résidence Internationale En Lorraine), le 20 décembre 2018

Claudine Armand 
Fig. 1

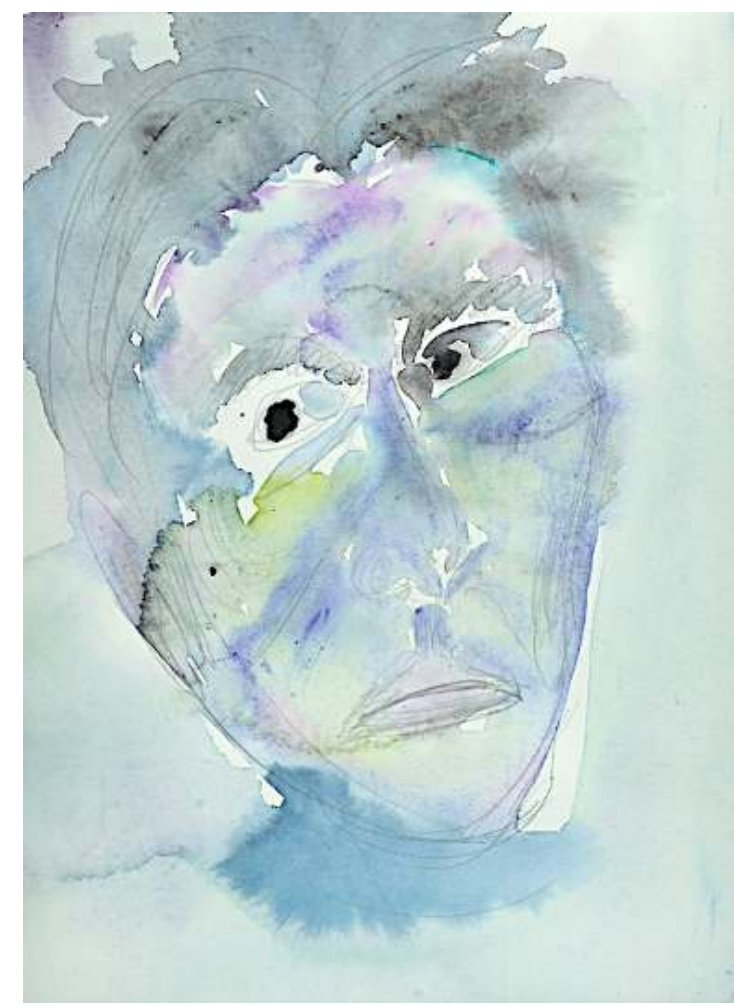

\section{SELF-PORTRAIT}

(C) Mark SaFranko

Claudine Armand: I will start out by asking a question about your childhood. Did you feel at an early age that you had a propensity for art?

Mark SaFranko: None whatsoever. That grew later, although I guess I was still quite young when I felt a propensity, but I didn't know what to do to express it so...but no, in childhood, none whatsoever.

CA: How old were you when you started to draw?

MSF: I was in my early twenties.

CA: Were your parents interested in art?

MSF: Not at all, not at all, they were both what you would call blue-collar workers, you know, living in an industrial city. They were both children of immigrants and my mother was forced to drop out of school at the age of twelve to go to work. My father went very early into the war and they had no sort of cultural awareness at all, they came from a very working class family.

CA: As you grew up, did you go to museums in New York?

MSF: No, not at all. Never, nobody went.

$\mathrm{CA}$ : Nobody encouraged you?

MSF: No, there was no encouragement whatsoever, and I'm not exaggerating. It's funny that you're asking me this question because I was thinking about these issues the other night as a result of watching something on TV. I'm still baffled to this day about how I ended up doing what I'm doing, I'm confounded by it in some ways, actually. No, there was no encouragement whatsoever. There wasn't a novel within miles of the house, in these industrial row houses, you know, that's where I lived and 
there wasn't a painting on the wall. There was religious iconography. I came from a very strict Roman Catholic family.

CA: You may have seen icons?

MSF: You did see icons. But whether that translated to Matisse or Picasso I don't think so [laughter].

CA: What's an ordinary day like and what time of the day do you draw? Is it an activity you do just to loosen up?

MSF: No, I actually have gone through periods of my life when I was quite serious about it. I know I'm a little self-deprecating about it, but I've put in a lot of work and I tend to draw and paint in the evenings after my hours of literary work are done. I find it very absorbing, like a Zen meditation. I often reflect on the differences between a literary life, a musical life, a painting life, and how really different they are and what they require from the whole organism in order to function and the very different processes, although they have the same source.

CA: Let's talk about your watercolors and the exhibition at the library. You've done a few landscapes, a few cityscapes and some still lives, but it seems that portraits and selfportraits dominate, right?

MSF: Right, and fish, I like fish. And you might call some of them abstractions too.

Fig. 2

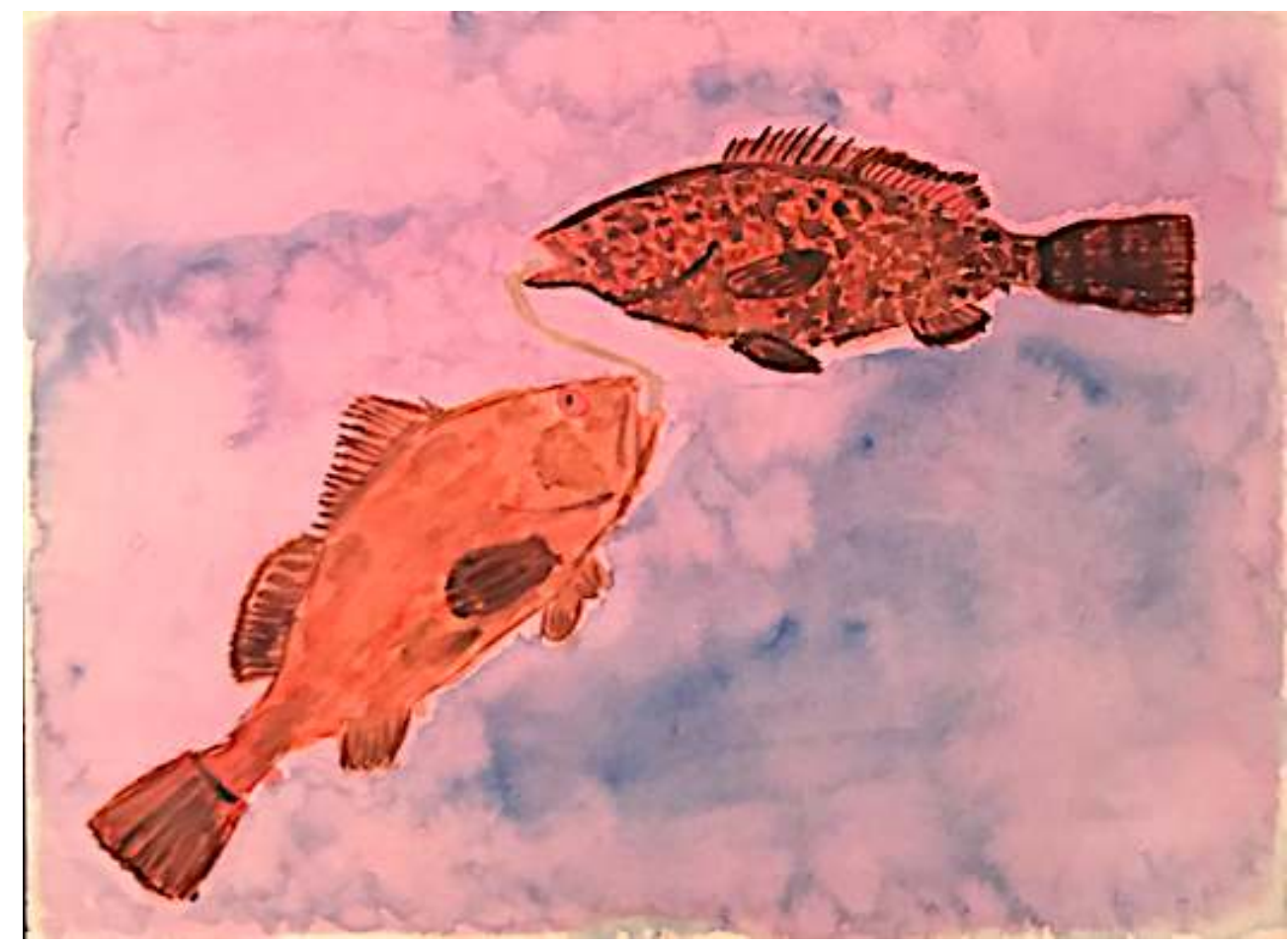

TWO FISHES IN THE CLOUDS

(C) Mark SaFranko

I try to sort of tackle everything, and there are some oversized paintings as well that are more complex than what we saw in the show. I didn't bring them with me for obvious reasons, I couldn't really transport them. There are a lot of other selfportraits, other fish that I brought, there are still lives, paintings of cluttered rooms, 
buildings, one of a house in Greenwich, England, one of a church in Greenwich Village in New York. There're probably some other abstractions, some whimsical paintings and there are paintings of vases.

Fig. 3

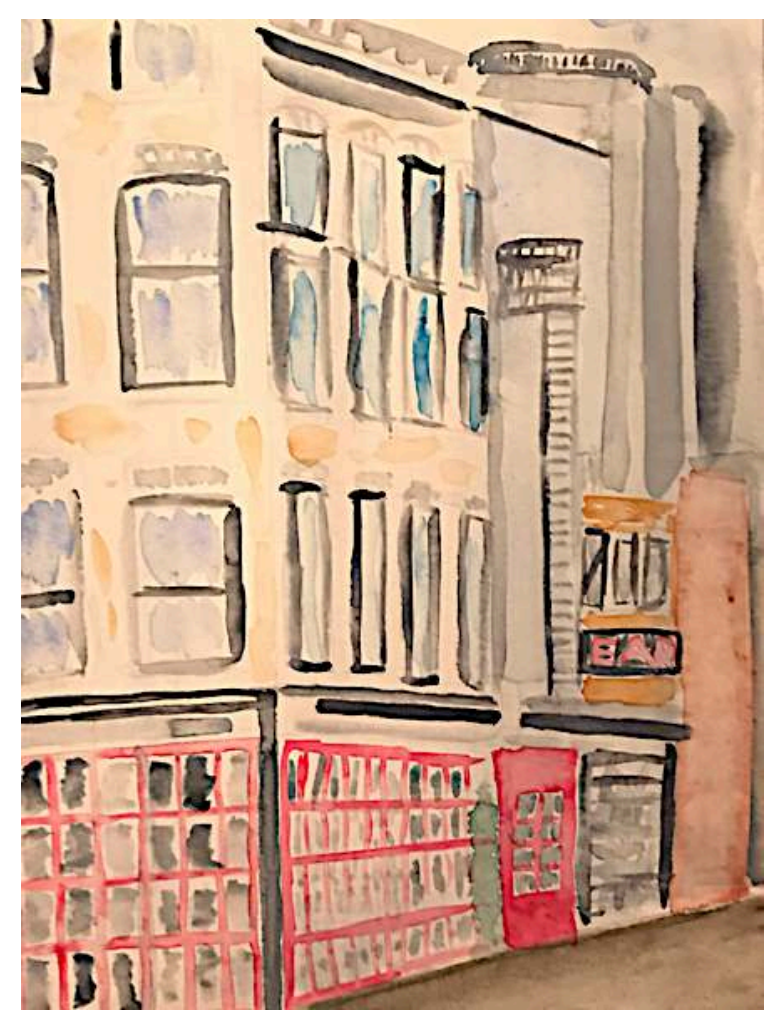

BAR IN SOHO

(C) Mark SaFranko

CA: As I was looking at the self-portraits the other day, I thought about the recurrent trope in art history of the artist and his/her model. Your self-portraits are frontal views, the figure stares out at the viewer, it never avoids the viewer's gaze. What accounts for the desire to represent yourself or to represent the self?

MSF: Perhaps it harkens back to what we were just talking about, where I came from and what I ended up doing in a way, which is sort of interesting. If I showed you a wide array of the self-portraits I've done, now that I think about it - I haven't really thought about it until now - but they look vastly different from one another. Early on I became quite fascinated with the idea or the notion of the multifaceted artist who has many identities, many voices, and many forms of expression. This goes back to people like Da Vinci really, who had a staggering amount of selves that always intrigued me. I always had the urge for multifaceted expression and I became, I don't want to say bored, but limited by doing just one thing. And while my literary work became ultimately the dominant piece of my life, I could never flush the other things out of my system. But to answer your question, I guess I was always intrigued, actually in many cases I used a mirror, I set up the mirror in front of myself, a large mirror and what comes out is really very interesting, the paintings are different one from the next, they differ vastly. I'm not sure why that happens because they're not realistic renderings of myself and sometimes I think the drawings themselves are quite good but I don't think they look anything like me, so it's a bit of a puzzle to 
myself actually. But perhaps it's easy, a somewhat easy thing to do to paint yourself or some rendering of yourself.

CA: I like the bluish self-portrait at the entrance of the show.

MSF: That's my favorite.

Fig. 4

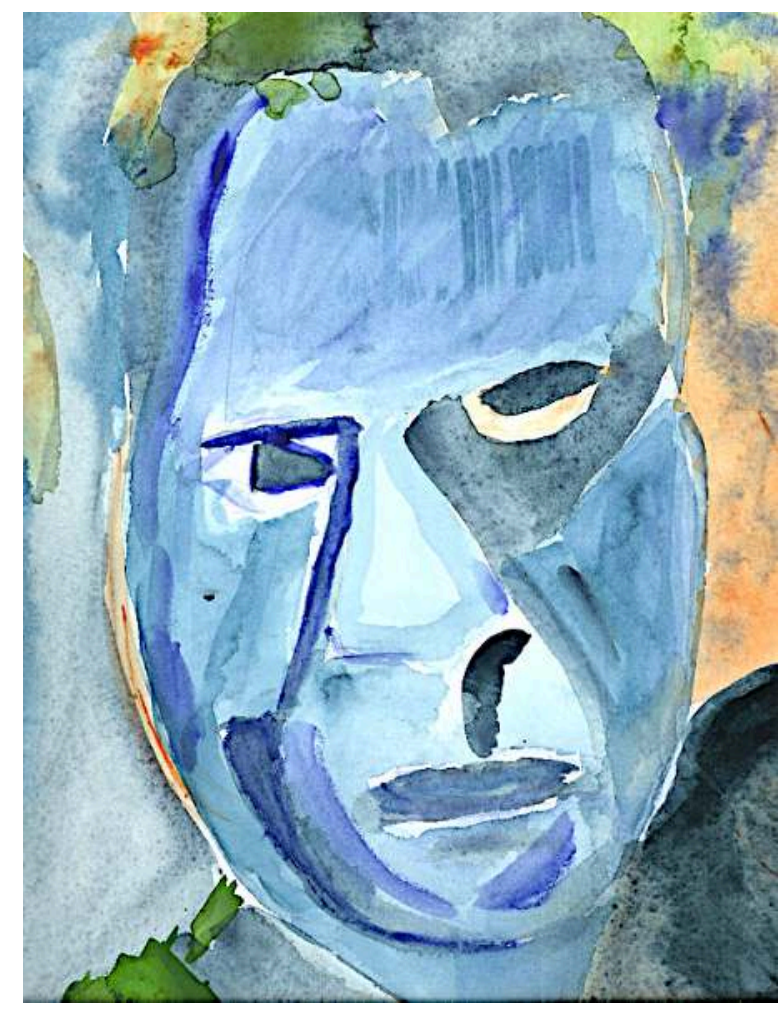

BLIND

(c) MARK SAFRANKO

That's actually a copy of another artist and his name slips my memory right now. It doesn't look like anything he did, but I was intrigued with the color schemes of the painting and I tried to execute my own version of it. But I'm blanking on his name, he was on the cover of an art magazine I saw one time.

CA: Is he a contemporary artist?

MSF: I believe yes, relatively contemporary, but you can see the roots of Rouault in it, for instance. There are many people that you can see in that artist.

CA: Painting self-portraits means looking inwards, trying to capture something invisible, but the revelation can only be partial, and so isn't self-portraiture a way of playing with one's own image?

MSF: Absolutely, it is.

CA: And a way of challenging the spectator, a sort of hide-and-seek game of appearing and disappearing?

MSF: I would say yes, except that in my case, my limitations as an artist probably subvert that notion to some extent. Sometimes when I'm dissatisfied with my basic rendering of something, I let it go into other areas and that's of course the beauty of the watercolor. You can do wash after wash, unlike oil, which perhaps gets a little bit 
more set in stone and you have to understand technically exactly what you want to render. I mean, the watercolor to me, a certain type of watercolor, is a much more playful means of expression and that always intrigued me about the medium. I learned that actually from Henry Miller, who was also obviously a well-known writer in France, an American writer who made his reputation in France. He was a lifelong aquarellist who often said he actually preferred being a painter to a writer and he spent many years working as a watercolorist, full-time at times, he did nothing but paint. His paintings are surreal, whimsical but they burst with a really interesting feeling of life. And I learned a lot from reading about his techniques in watercolor, so he was a central influence for me. And then, of course, there are certain artists that one could never hope to... I mean John Marin for me is probably the greatest watercolorist who ever lived. He also spent a lot of time in France, but to me, he took the medium into a completely different phase and I hesitate to even know what to call it, he could do anything with watercolor. But there are so many other great artists, like Paul Klee, another one I greatly admire, or Kandinsky. I like $20^{\text {th }}$ century painters who have left the formal behind and painting became a different thing. I mean obviously that has its roots in Picasso and Matisse and Cézanne, who is maybe the greatest master of the medium. But all the works of those painters reveal the incredible range of things you could do with the medium. I mean I know some people consider it inferior to oil painting, but I never did and it's the accident that comes with the form that to me is absolutely fascinating, when the painting bleeds to one side of the paper and there's this effect that you didn't intend but looks spectacular whether or not it's artistically, you would call it, accomplished.

CA: John Marin was influenced by Cubism and Futurism. There's a lot of energy, force, and movement in his watercolors, as we can see in the Brooklyn Bridge series with its dynamic compositions.

MSF: He was very much influenced by what was going on in Europe because he spent years here before he went back, and I always found New York skyscrapers, the way he makes them tilt toward each other, to be fascinating. There's a tension in it.

\section{CA: It's very unstable.}

MSF: Very. He's a very unusual painter. I'm a little surprised that people don't talk about him more. You know, when you think about the history of watercolor, he in many ways to me, is the bridge between a more classical expression and the modern age, and people don't talk about him that much, I mean he's not in the conversations one of the names that you always hear.

CA: Marin was close to Alfred Stieglitz, the great modern photographer of New York. I was wondering if you're also interested in photography?

MSF: Secondarily. My wife takes much better pictures than I do. She's much more interested in photography and I'm not sure why I don't take pictures because I'm vitally interested in cinema, in filmmaking, but still photography has just been something I've never spent any time with. The last thing I wanted to add to my record was filmmaking, but it's kind of late for that now in my life, and you need millions and millions of dollars to do it half decently, although the technology's changed now, but having worked as an actor and seen the ins and outs of the theater and film world, it's very complicated and to do it well you need a lot of expertise around you. And that means you have to have money. And I don't know that I could live for several years with nothing but one script, because that's what you have to be 
able to do. Very few filmmakers, except perhaps Woody Allen, can make a film every year. It's impossible because of the money involved. And even really highly successful, critically successful filmmakers scramble for money, so it's really hard to do and a couple of times I came close to trying, but perhaps thought better of it in the end and didn't.

CA: Do you enjoy looking at photographs?

MSF: Yes, some. Diane Arbus is an interesting photographer, obviously, to me. I appreciate photographs but I don't spend a lot of time...I'd rather look at paintings, which brings me actually to...I was at the Pompidou Center this past weekend in Metz, and there was an interesting exhibit on color. I don't know if you've seen it?

So you have color, and then the top two floors were paintings. I couldn't help thinking that I appreciated the top two floors much more than I did the bottom two floors, and I was thinking about how those first two floors, which were about color, were rebellions against tradition, like people want to go beyond the confines of the canvas but I'm not so sure how successful it ever is. I don't know what you thought. I'm not so sure that it's as successful as that old form, you know, where you take the paintbrush and you do what you have to do in a confined space. I understand the urge to rebel against it because if you've read the words of the people working on the first two floors, they're struggling to break out of the confines of the traditional, but for myself I'm not sure how successful it is all the time.

CA: That's the exhibit Painting the Night?

MSF: Yes, that's what I've been referring to, the two top floors.

CA: I haven't seen it yet.

MSF: Oh it's great.

CA: Can we paint the night?

MSF: A lot of people did a very good job of it. Yes, I think so. That was the highlight of the whole exhibit, I thought, Painting the Night.

CA: You said you like $20^{\text {th }}$ century art. Watercolor was also the favorite medium of the Modernists thanks to its capacity to catch fleeting moments of life and the potential of the white paper which, to me, is akin to the writer's white page or the painter's blank canvas. Watercolor is a tough and challenging medium, isn't it?

MSF: It is, and it's very exciting.

\section{CA: Because you can't go back to it?}

MSF: No, you can't go back to it, that is true. You can't go back to it but you can transform it constantly, you know, you can take a painting like that and just paint over it, completely and use that as a wash. So it can be transformed endlessly, of course it becomes a big mess, that's theoretical, it will become a big mess but you can transform what starts out as an abortion of sorts into something interesting. But I'm not so sure. Don't people always revert to oil in canvas though? I mean, they always seem to revert to it - why is that, when watercolor does give you a tremendous amount of possibilities?

CA: I guess with oil you can add more layers and therefore totally transform the texture.

MSF: That's true. People always say watercolor is hard, I don't know why. It is hard but I hope for something that looks interesting, colorful, and beautiful in some way, 
and since I'm not really a representational painter, the accidents in watercolor can be very fortuitous and come out looking really interesting.

Fig. 5

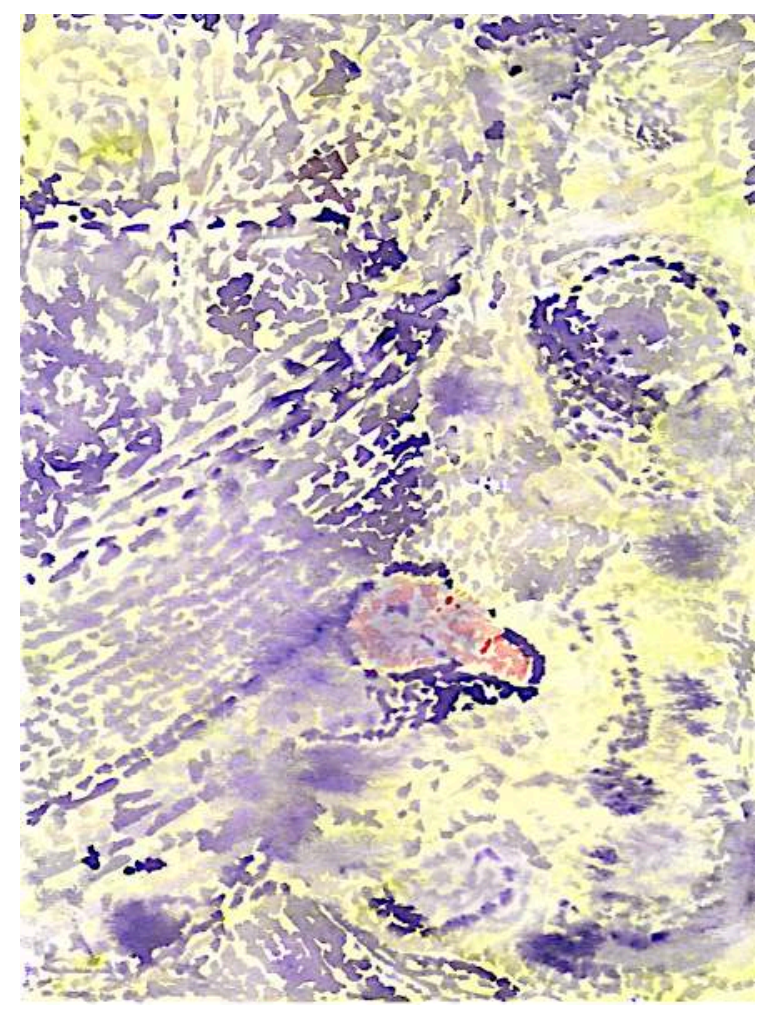

ANCIENT FACE

(C) MARK SAFRANKO

CA: I had another look last night at the Self-Portrait with Three Eyes, which is just in front of us when we enter the exhibition room. Is it a wink at Picasso when he portrays Dora Maar or women with disjointed features and asymmetrical eyes, as in Les Demoiselles d'Avignon? 
Fig. 6

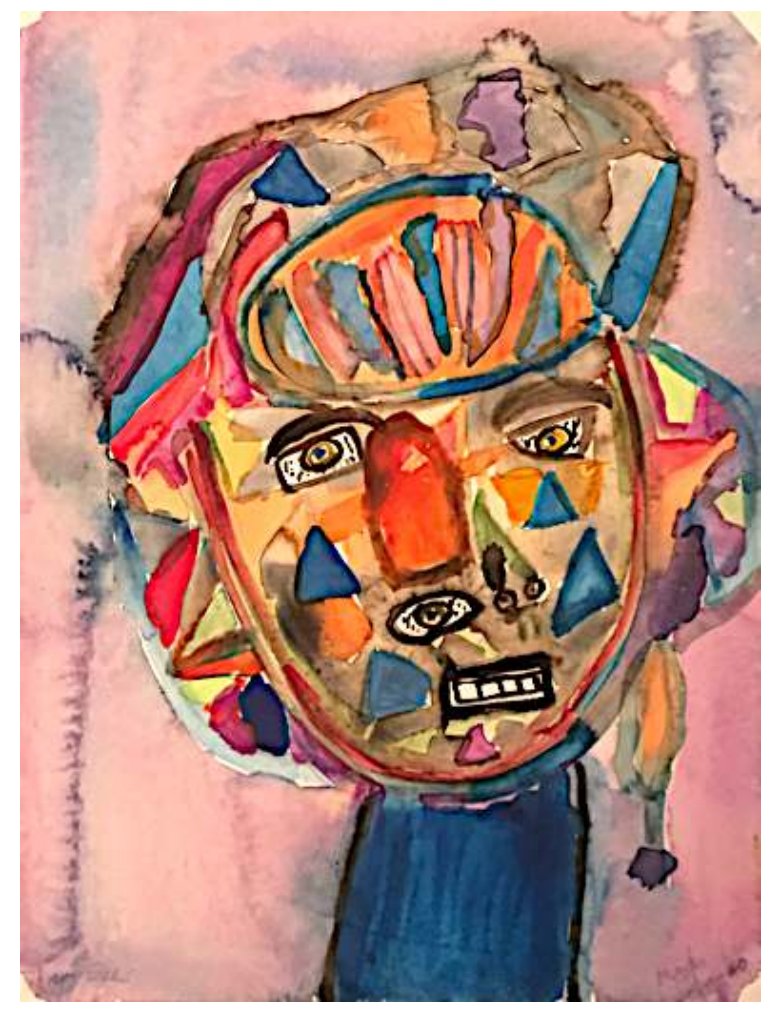

THREE EYES

(C) MARK SAFRANKO

MSF: No, honestly that painting was the result of enormous frustration. I had done a couple of watercolors and was very unhappy with what was coming out and just slathered a lot of paint and said, you know, since I can't do anything right now that I like, I'm just going to go crazy and just put anything into this. Someone mentioned Basquiat with that painting, and perhaps there's a little bit of that.

CA: I don't really see a parallel with Basquiat.

MSF: No.

CA: The figures in Basquiat's portraits are more skeleton-like, aren't they?

MSF: Right. Perhaps some of the distortions in that watercolor you were referring to are what people picked up. To answer your question, it's not a conscious wink at Picasso.

CA: I'm interested in your use of color. I suppose you like the fish because they have so many colors, and nuances, and textures?

MSF: Yeah, I find them relatively easy to render as well. I've done a lot of fish. The colors in fish are fascinating to me. I actually tried to draw some reptiles, like snakes, because their scales, the color patterns on the scales are stunning. People don't realize that you have to see them in full sunlight to appreciate them, but they're surprisingly difficult to render well. So the fish I revert to because I think there is a simplicity in the form and then you can do a lot of interesting things once you have the form in place and they come in such variegated colors. 
CA: I love the little beach houses on stilts. This watercolor exudes so much warmth and it reminds me of Matisse. I suppose Matisse is an inspiration for you?

MSF: You know, you can't get around him. To me, he's maybe the most indispensable artist in many ways. The color in Matisse is unique and I don't think you've ever seen this in any major artist, there's a simple rendering of the magic of life in all of Matisse, that's why I love his work. I've come to more and more grudging love of Picasso, who in some ways I did not understand when I was younger because he can be cold and sometimes more difficult to appreciate. But there's no getting away from Matisse.

Fig. 7

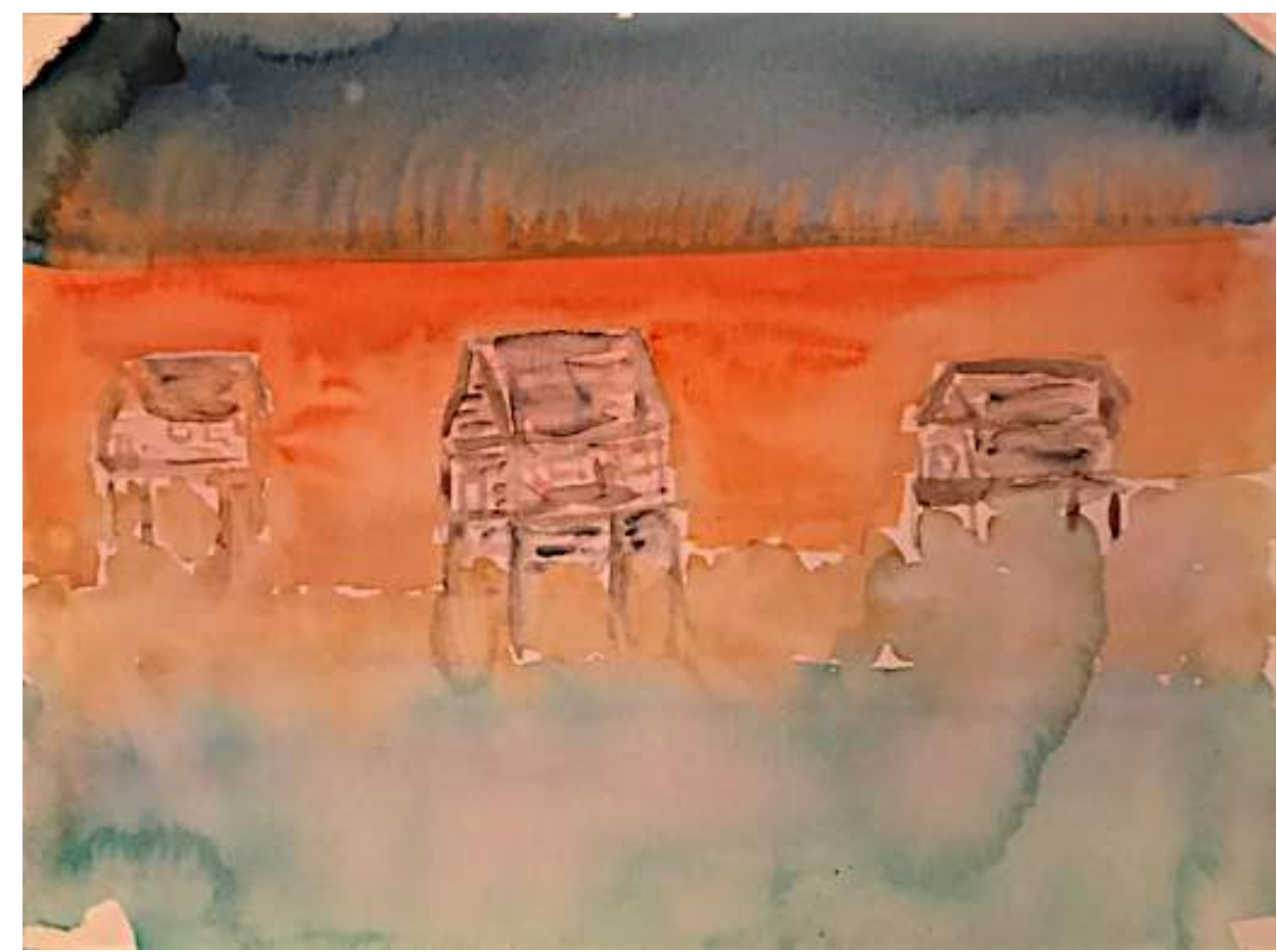

THREE BEACH HOUSES UNDER STORM CLOUDS

(C) MARK SAFRANKO

CA: So do you use color for its expressive values?

MSF: Absolutely.

CA: And/or is it to draw attention to the picture plane as Abstract Expressionist artist Hans Hofmann did with his push and pull technique?

MSF: My use of the paint is so instinctive that I have a difficult time answering that question. Once I start, I try to achieve some striking visual value, and that comes about through a really judicious use of color and paint. I've ruined many watercolors by not knowing when to stop, so it's a fine line that one treads as a watercolorist that you have to know how and when to stop. 
Fig. 8

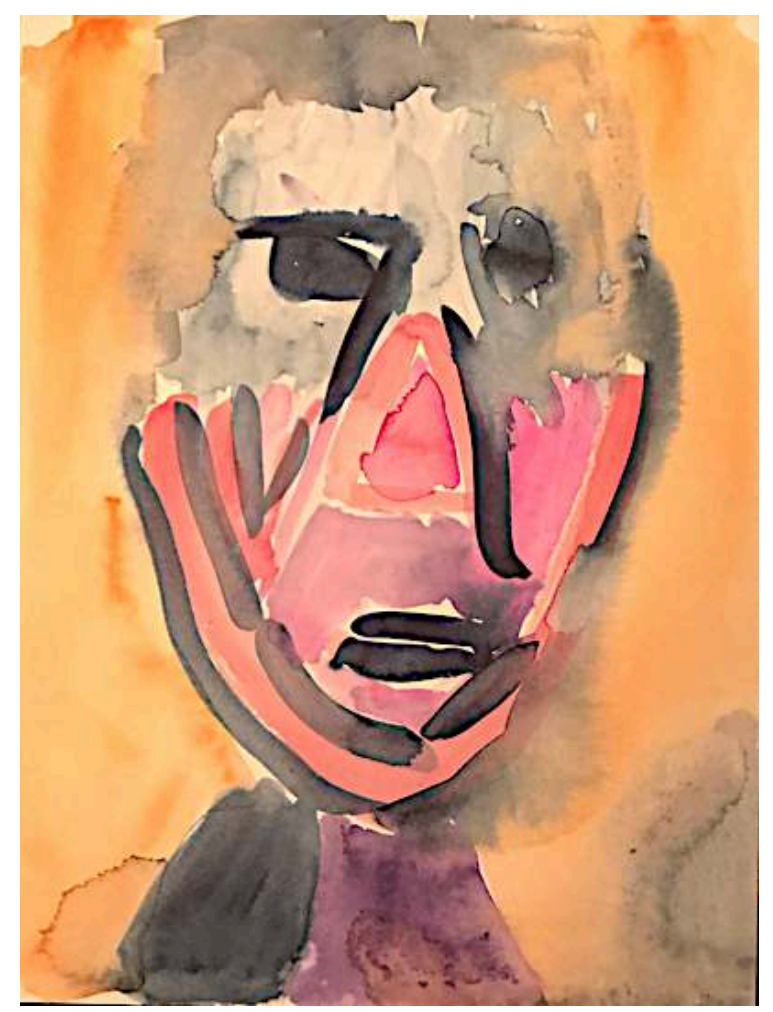

SELF-PORTRAIT

(C) MARK SAFRANKO

CA: In your novels and short stories there's a special mood that, in my opinion, is evocative of Edward Hopper, in particular his engravings Night Shadows and A Corner. Do you agree?

MSF: I do. I don't know if you've read the Max Zajack novels, which are very different from the ones I believe you've read - the psychological suspense, the crime-based novels, they are somewhat Edward Hopper, yes - but the Max Zajack novels are very different and a lot of the short stories are different from each other, so I'm not sure that it's always there, but that's one segment of them.

CA: How do you respond to abstract art and to the American Abstract Expressionists like Barnett Newman, Mark Rothko, those artists who forged a genuine American art form?

MSF: I like some of them, others I don't. Sometimes I think they work better than others, and I really don't feel qualified to speak about this on one level because I'm not an art critic. Perhaps they don't speak to me as vitally as some other forms do, but when you look at someone like Paul Klee, let's say, for me they're much more alive. The watercolors could be triangles or boxes, I don't know what he's doing sometimes, but to me, they can be much more vital and alive than...

CA: Than a Barnett Newman?

MSF: Yes.

CA: How do you respond to works that intermingle the visual and the aural, like Mark Rothko's monochromatic paintings in Rothko's Chapel in Houston combined to Morton Feldman's minimalist music?

MSF: I'm actually more fascinated with the minimalist music than I am with the painting. I have an appreciation for some of the works by Rothko but I'd rather look 
at Lucian Freud, a great favorite of mine. To go back to the music, I'm totally intrigued by John Cage, that sort of complete dissociation from formal music is fascinating for me. I have a couple of instrumental albums out which flirt with Cagean, I'd say, ambient music or cinematic music. All these categories can be very misleading in a way, that's why I'll pick the artist rather than the school, because ultimately art to me is solely what you, as a viewer, listener, or reader respond to. It's a matter of opinion, it's a matter of your own psyche, there's no right and wrong. When it comes to art, we all simply have our preferences and I always like to say that art is not golf, where nowadays, especially when the camera's on the player, you cannot make a mistake. It's a game which I appreciate in some ways because you have to be the best player to win. In art anything is possible, your likes are as good as mine or hers.

CA: You mentioned Lucian Freud. Do you like his self-portraits?

MSF: I love them, I love the self-portraits.

CA: Why?

MSF: Very difficult to put into words. They just appeal to the eye. But perhaps my favorite modern painter - I find him absolutely fascinating although I guess he's been a fad in the New York downtown scene but I think he's incredible - is Eric Fischl. The paintings are so soaked in psychological nuance that they are absolutely like miniature cinema to me in a way, or cinema on canvas and yet they achieve this effect by virtue of a single image. I don't know, but he's always fascinated me, Eric Fischl.

CA: I heard on YouTube, a piece of music of yours called Francis Bacon: A Painting in Sound "which consists of a collision of various music instruments, sounds, voices, and screams.

MSF: And gunshots.

CA: Could you explain what triggered this piece?

MSF: I had long been a great fan of Francis Bacon, I considered him one of the great painters of all time, and I wanted to create a soundscape that really threw off all form and that was the result. I just laid layer after layer of noise down and spontaneously, although running through that song are pieces of another song that I wrote. You can hear it in parts as it makes its way through the piece. I got my son to play piano and drums on that as well, and I played the vast majority of the instruments but he's actually on that recording, which is very rare for me because now I play all instruments myself, in the service of time and efficiency. I play many different instruments.

CA: Amazing.

MSF: Well I don't know, but anyway, that's interesting, I don't know what you thought of that when you listened to it?

CA: I liked it.

MSF: You liked it?

CA: Yes, I liked its heterogeneity and the way it reached a cacophonous crescendo.

MSF: I had a good time with that. I'm not sure...there was one part of it that I didn't like, which the listener would never pick up, but I didn't like the series of gunshots in it, there were a couple of repetitions of the gunshots, and I really should have taken one of them out. 
CA: Francis Bacon and Lucian Freud were very close friends. In an interview with David Sylvester, Bacon once said2: "The sitter is someone of flesh and blood and what has to be caught is their emanation. I'm not talking in a spiritual way or anything like that - that is the last thing I believe in. But there are always emanations from people, whoever they are, though some people's are stronger than others." How do you understand this statement?

MSF: My first response is that the emanation is definitely coming from the sitter, meaning the model, and I mean, in Bacon's work you have the emanation of almost all that is hideous in the human corporeal and psychological beings. He catches obviously the grotesque, the distortions that are the product of our...I'm trying to find a word that works adequately, I want to say 'demonic' selves but that may be too extreme. It's something else, it's another word that I want to use and I can't think of what it might be right now. Not demonic so much as...[Silence].

\section{CA: Monstrous?}

MSF: Monstrous is a good word and perhaps, you know, other people have...Picasso has done the same thing, but perhaps no one more effectively than Bacon.

\section{CA: What do you think of the "screaming" popes?}

MSF: It's a fascinating series, but all of his stuff is. I just looked at it the other day, I saw a retrospective exhibition of Bacon at the MET just a few years ago. It was overwhelming.

CA: I see a close link between your writing and your music. Writing implies constraints whereas watercolor partakes of a more playful practice, doesn't it?

MSF: I think it does. People have tried to do in writing what a playful watercolor achieves but I'm not so sure that the results are as pleasing or effective, but that's me, I feel I have to be a writer again when I write, whatever that means, and when I'm a painter, I'm doing something completely different.

\section{CA: Would you say it helps to find a sort of balance?}

MSF: Oh, I think all of those things are an attempt by me to find a psychic balance, no question about it. I need them for psychic balance and one of the reasons I wrote those Max Zajack novels, which are sort of autobiographical, and then The Suicide and these other novels that are crime or literary or whatever, is because when I'm doing one I need after a while, after being submerged and immersed in one form, I need to change it, again for psychic balance, I think. I get bored too with the same thing over and over again, I find it makes me stale but since I still have energy to do something I go to a different medium or a different type or novel or story, whatever it might be.

CA: To go back to the self-portraits, when I look at some of them, I'm reminded of Andy Warhol's camouflage self-portraits, or his portraits in profile like The Shadow. In your selfportraits, the figure looks rather distant, a little austere even, and they sometimes have a mask-like quality. French philosopher Jacques Derrida said that the painter who makes his self-portrait only captures his own ruins, his "specter."3 I was wondering how you react to that statement.

MSF: That's interesting, there's a great deal of truth in it. Actually this harkens back to what I often say about the writing. As soon as you apply pen to paper or finger to a keyboard, the truth is distorted and becomes something else. You can never capture the entirety of yourself or experience or even a moment accurately because as soon as it comes out, it is distorted. I think Proust came very close, and even a book like Tropic of Capricorn by Henry Miller or maybe Céline's first two big novels, they came close to trying to harness and really capture the authenticity of a life lived on 
simultaneous and different levels, but it's ultimately always unsuccessful, for one reason or another, because so much is brought to bear on one moment of human experience. It means your entire history, everything around you, in the environment, it's impossible to capture because of all the complexities that go into that, and how it's filtered through human consciousness. I don't mean this to sound extremely pretentious, I'm trying to explain how one arrives at whatever the truth is, and does that really matter in the long run anyway? Is our whole spectrum of experience a whole series of self-deceptions anyway? Is there such a thing as truth? I don't think there is, so I think that what the philosopher was saying is true, but perhaps it doesn't go far enough, in a way. That's a complicated answer...I don't know, coming from me it's probably a pretty accurate answer about what I'd like to say about that. I hope it makes some sense - I don't know if it does.

Fig.9

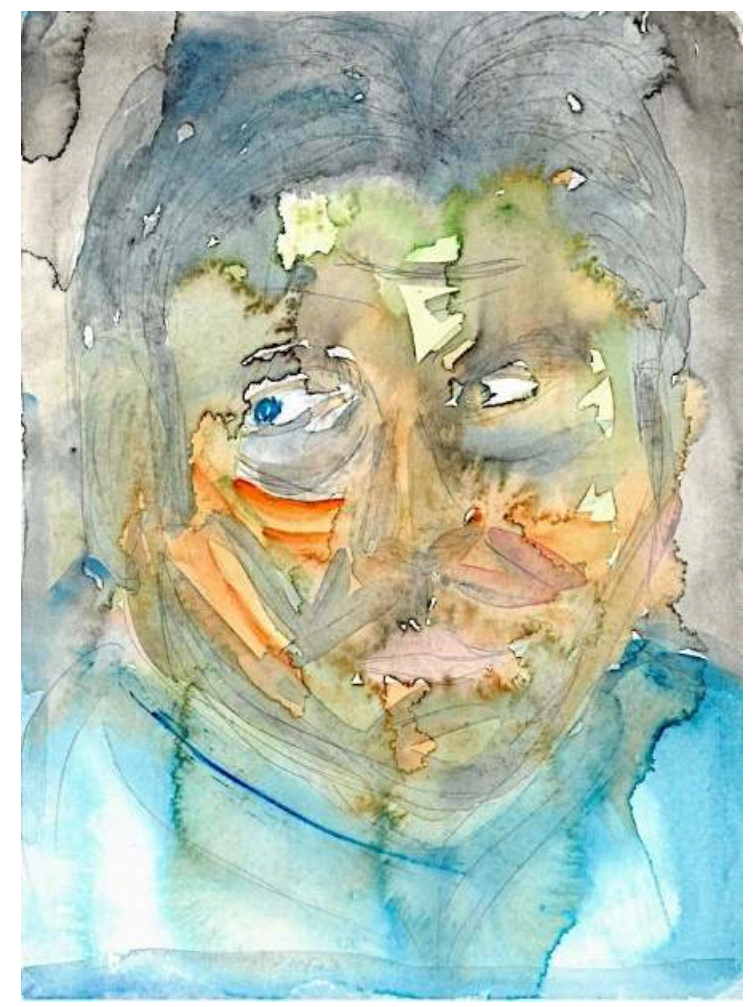

DISTORTED FACE

(C) MARK SAFRANKO

CA: In one of your lectures you said that "works of art are never finished, they are abandoned."

MSF: It's not mine, but I do like it though.

CA: What do you mean by "abandoned"?

MSF: I think that we're all sculptors. Let's say we have a block of granite or marble, and you have an image in your mind of what you'd like to execute, and you go about trying to do that and obviously some of the Renaissance masters came as close to perfection as anyone has, but for myself I think you have something you want to execute, and you do your best to achieve that execution. And then after trying over and over and over again to achieve this perfection, you realize that it's impossible, 
and hence the work is abandoned - that's how I interpret that. Some of my other favorite sayings about all of art and this go for painting as well: it was Somerset Maugham who said: "There are three rules for writing the novel. Unfortunately, no one knows what they are." That's one of my favorites, and the late William Goldman, the screenwriter and novelist who just died very recently, famously said, and I think this is true, when he talked about the art of movie making: "No one knows anything." And what he was referring to there was that no one really understands how to make a really good movie, they are accidental and that applies to art too.

CA: I suppose that self-portraiture as a subject matter is related to your interest in "human character"?

MSF: Yes, that's true. Let's take the blue self-portraits, we can call them self-portraits, but they don't look like me and any affect or meaning is really brought by the viewer. I wouldn't know what to say about that in terms of myself - I mean, what is it? I don't know. It says something, but what does it say? I think that's more in the viewer's eye.

CA: In the eye of the beholder.

MSF: Absolutely.

CA: Finally, who are you, Mark SaFranko? Andy Warhol used to say: "If you want to know all about Andy Warhol, just look at the surface of my paintings and films and me and there I am. There's nothing behind it." ${ }^{4}$

MSF: I guess there's a great deal of truth in that. I wrote a song, in fact I'm playing a solo show in Besancon on January $23^{\text {rd }}$ and I haven't done a show on my own for years now but I'll end it with a song that I think is one of my best, called "I Still Don't Know Who I Am." It's out there on Spotify and I think it's one of my best songs, it kind of like sums up my feelings about myself. I don't know, and it goes way back to what we were saying at the beginning, which is I'm baffled about how I got to where I got, I have no idea how or why. Coming from my background, I have no clue how I actually ended up where I ended up, I don't really know. But that's a good quote from Warhol.

CA: Is Warhol an artist you like?

MSF: Not particularly. My only Andy Warhol story is that one year my wife and I went to the New York Art Expo, which is held in the Jacob Javits Center, it's a huge hall where they do car shows and the book fair is there but they do this art show, and I went up to buy my ticket to go in and standing in front of me was Andy Warhol. So that was sort of interesting, he was right in front of me.

CA: Wearing a wig?

MSF: The wig stood out like a sore thumb. And I realized, interestingly, that one thing that does sort of intrigue me about Warhol is that we come from the same Eastern Catholic Church Rite, because he comes from the same exact area that I do in Europe, and my father was in the Greek Catholic Church, they came from the same Greek Eastern Rite Church.

CA: And he changed his name.

MSF: Yes, his name was Andrew Warhola.

CA: What about your name?

MSF: It's a Slovak name, but it underwent some kind of a mutation. It got the capital $F$ which is a little Balzacian in its pretentiousness, and people often mistake it for an Italian name, which it's not because of the "ko" in it. Actually there are Jewish 
families with the name, which I don't quite understand, and I see that nowadays most of the SaFrankos with that spelling are in Croatia, Hungary, and Slovakia.

CA: Finally, are all those activities - writing, drawing, composing, playing music - part of the numerous pieces of the puzzle that the reader/viewer/listener is to bring together to get a better grasp of Mark SaFranko?

MSF: I would think that would be it, yes. I would think so but... [silence], you know, I'm not so sure that it does capture the whole of who I am because in each one of those perhaps something of a persona emerges, and what's missed and what is not visible, is the profound self-doubt, anxiety, depression maybe, that lies behind some of these activities and it's not seen - well maybe it is seen, I don't know, I don't know. Again, that's more for the viewer to sort of decide. I can't remember his name, he's a writer, he's dead now, but he said "no writer writes about anything but himself," and I immediately responded to that because even with all of these masks that I wear, it's all me there but I don't know how full the portrait is.

\section{Fig.10}

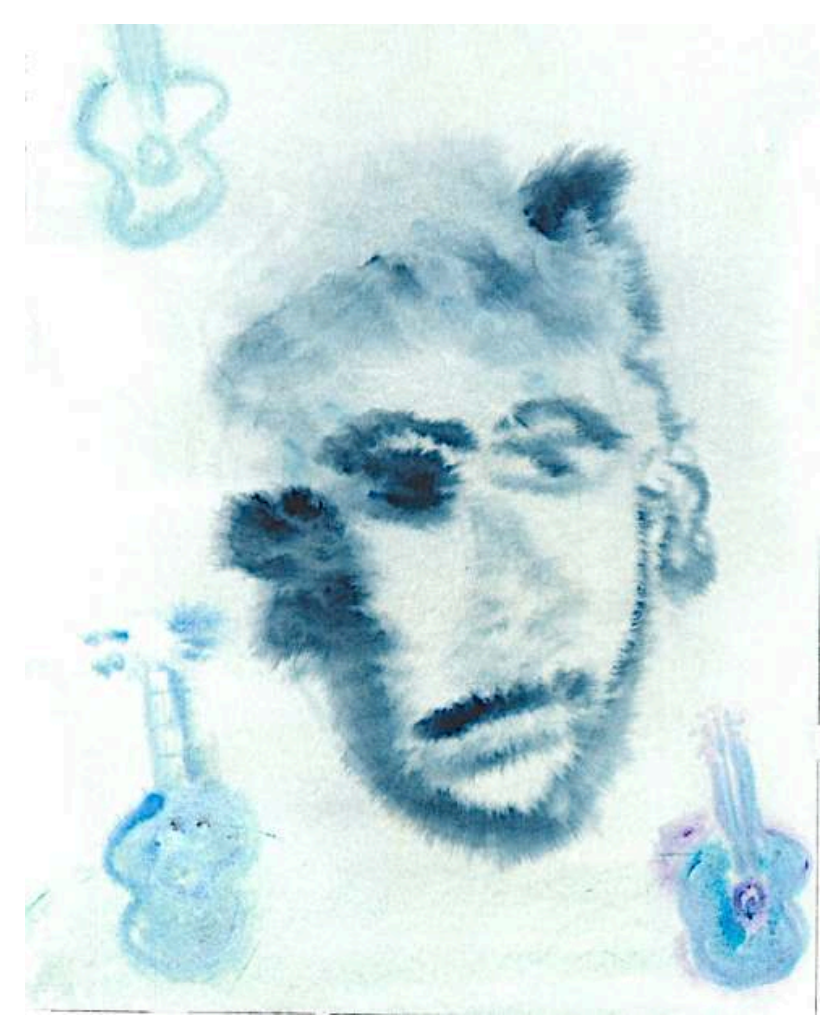

\section{FACE WITH GUITAR}

(C) MARK SAFRANKO

\section{CA: And who is that "me"?}

MSF: That's a good question. Who is it? Or you could make the case that there's nobody there, and this is all an attempt to construct somebody, an attempt to construct something because I certainly didn't feel, you know, that great about myself as a kid, but other people might say that there's evidence of a very strong ego in all of this too. So what's the truth? What's the truth? 
CA: Those can be the final words.

MSF: What is the truth?

CA: Thank you so much, Mark.

\section{NOTES}

1. https://www.youtube.com/watch?v=rY9hlcpjg2I

2. David Sylvester (ed.), The Brutality of Fact: Interviews with Francis Bacon. London: Thames \& Hudson, 1987, 174.

3. See Memoirs of the Blind - The Self-Portrait and Other Ruins. Chicago: University of Chicago Press, 1993.

4. Andy Warhol, Interview with Gretchen Berg, "Andy Warhol: My True Story," 1996, in I'll Be Your Mirror: The Selected Interviews with Andy Warhol. Kenneth Goldsmith (ed.). New York: Carroll \& Graf Publishers, 2004, 90.

\section{ENDNOTES}

i.

INDEX

Keywords: visual art, self-portraiture, watercolor, text, image and sound Subjects: American art

Mots-clés: arts plastiques, autoportraits, aquarelles, rapports texte/image/son

\section{AUTHORS}

\section{CLAUDINE ARMAND}

Maître de conférences

Université de Lorraine

Claudine.Armand@univ-lorraine.fr 